\title{
Changes in Fat Mass Following Creatine Supplementation and Resistance Training in Adults $\geq 50$ Years of Age: A Meta-Analysis
}

\author{
Scott C. Forbes ${ }^{1, *}$, Darren G. Candow ${ }^{2}$, Joel R. Krentz ${ }^{1}$, Michael D. Roberts ${ }^{3,4}$ and \\ Kaelin C. Young ${ }^{3,4}$ \\ 1 Department of Physical Education, Faculty of Education, Brandon University, \\ Brandon, MB R7A 6A9, Canada \\ 2 Faculty of Kinesiology and Health Studies, University of Regina, Regina, SK S4S 0A2, Canada \\ 3 School of Kinesiology, Auburn University, Auburn, AL 36849, USA \\ 4 Department of Cell Biology and Physiology, Edward Via College of Osteopathic Medicine-Auburn Campus, \\ Auburn, AL 36849, USA \\ * Correspondence: Forbess@brandonu.ca; Tel.: +1-204-727-9637
}

Received: 26 June 2019; Accepted: 21 August 2019; Published: 23 August 2019

\begin{abstract}
Aging is associated with an increase in fat mass which increases the risk for disease, morbidity and premature mortality. Creatine supplementation in combination with resistance training has been shown to increase lean tissue mass in adults $\geq 50$ years of age; however, the synergetic effects of creatine and resistance training on fat mass in this population are unclear. Creatine metabolism plays an important role in adipose tissue bioenergetics and energy expenditure. Thus, the combination of creatine supplementation and resistance training may decrease fat mass more than resistance training alone. The purpose of this review is two-fold: (1) to perform meta-analyses on studies involving creatine supplementation during resistance training on fat mass in adults $\geq 50$ years of age, and (2) to discuss possible mechanistic actions of creatine on reducing fat mass. Nineteen studies were included in our meta-analysis with 609 participants. Results from the meta-analyses showed that adults $\geq 50$ years of age who supplemented with creatine during resistance training experienced a greater reduction in body fat percentage $(0.55 \%, p=0.04)$ compared to those on placebo during resistance training. Despite no statistical difference $(p=0.13)$, adults supplementing with creatine lost $\sim 0.5 \mathrm{~kg}$ more fat mass compared to those on placebo. Interestingly, there are studies which have linked mechanism(s) explaining how creatine may influence fat mass, and these data are also discussed.
\end{abstract}

Keywords: body composition; nutrition; supplement

\section{Introduction}

The prevalence of obesity (body mass index $\geq 30 \mathrm{~kg} / \mathrm{m}^{2}$ ) in aging adults has risen substantially over the past few decades, with the highest rates in adults 60-75 years of age [1]. Specifically, intramuscular and visceral fat typically increase with minimal change in subcutaneous fat [1]. The age-related increase in fat mass is associated with greater risk for disease (i.e., cardiovascular disease, type II diabetes, obesity), morbidity and premature mortality [2]. Although multifactorial, one possible contributing factor explaining the age-related increase in fat mass is sarcopenia. Sarcopenia, defined as the age-related reduction in skeletal muscle mass, strength and physical performance [3], decreases physical activity, energy expenditure, and metabolic rate [4,5]. Therefore, lifestyle interventions which help overcome sarcopenia may also have a favorable effect on reducing fat mass in aging adults [6,7].

Resistance training is an effective lifestyle intervention for increasing muscle mass and strength in aging adults (for reviews see Hart and Buck [8]; Lopez et al. [9]). Additionally, resistance 
training increases participation in physical activity and activities of daily living leading to increased energy expenditure, metabolic rate and fat loss [10]. Combined with resistance training, dietary supplementation with creatine, a nitrogenous organic acid derived from reactions involving arginine, glycine and methionine in the liver and kidney [11], has beneficial effects on aging muscle. Three meta-analyses have been performed involving creatine supplementation during resistance training in older adults [12-14]. Collectively, results showed that the addition of creatine to resistance training significantly increased muscle mass $(\sim 1.21 \mathrm{~kg})$, possibly by influencing high-energy phosphate metabolism, muscle protein kinetics, inflammation and oxidative stress, satellite cell activity and the expression of growth factors (for review see Candow et al. [15]).

Although most individuals supplement with creatine to increase muscle mass and/or muscle performance, rodent and in vitro studies provide mechanistic evidence suggesting that creatine also influences fat bioenergetics and energy expenditure [16-19]. Therefore, a review focusing on fat mass is warranted despite several recent reviews on creatine and resistance training in older adults that have focused on muscle mass and strength. Furthermore, individual human studies examining creatine supplementation on fat mass are mixed, with some showing a decrease in fat mass whereas others have shown no effect (Table S1). Since the variability in the responsiveness to creatine supplementation is high in adults $\geq 50$ years of age, and individual studies typically lack statistical power for detecting significant differences, it is important to determine with greater certainty whether creatine influences fat mass in adults $\geq 50$ years of age. Therefore, our purpose was two-fold: (1) to perform meta-analyses on studies involving creatine supplementation during resistance training on fat mass in aging adults, and (2) to discuss possible mechanistic actions of creatine on reducing adiposity. This review is novel since, to our knowledge, it is the first to examine the impact of creatine on fat mass in aging adults.

\section{Materials and Methods}

Articles were selected for full-text review if they met the following criteria: (i) randomized controlled trial where participants were allocated to a creatine ( $\geq 2$ grams per day) or a placebo treatment condition and resistance training; (ii) the mean age was $\geq 50$ years; (iii) intervention duration $\geq$ five-weeks of $\geq$ twice per week of resistance training (to provide sufficient time and stimulus to demonstrate observable changes in fat mass); and (iv) include either absolute fat mass (kg), body fat percentage $(\%)$, or body mass changes $(\mathrm{kg})$ over time. We included studies that combined creatine with other nutritional supplements (e.g., whey protein), but also ran our meta-analyses without these studies to determine whether they influenced the final outcome measures. If the outcome data was not able to be extracted, authors were contacted for missing information. Data extracted included pre- and post-training means and standard deviations (SD) or change scores for outcome variables and SDs for the change scores. When pre- and post-training means were extracted, change scores were calculated as post-training mean subtract pre-training mean. SDs for the change scores were estimated from preand post-training SDs (SDpre and SDpost) using the following equation derived from the Cochrane Handbook for Systematic Reviews of Interventions:

SD change score $=\left[(\text { SDpre })^{2}+(\text { SDpost })^{2}-2 \times(\right.$ correlation between pre- and post-scores $)$ $\times$ SDpre $\times$ SDpost $]^{1 / 2}$

In this equation, we used 0.8 as the assumed correlation between pre- and post-scores. Meta-analyses were run using RevMan 5.3 software (Cochrane Community, London, UK).

A fixed effect model was used. Weighted mean difference was calculated for all outcome variables, along with the $95 \%$ confidence interval (CI). Forest plots were generated for study-specific effect sizes along with $95 \%$ CIs and pooled effects. A p-value $\leq 0.05$ was considered statistically significant. Statistical analysis for heterogeneity was assessed using chi-square test for heterogeneity and the $\mathrm{I}^{2}$ statistic to quantify total variation across studies attributable to heterogeneity. Funnel plots were generated and visually inspected for publication bias. 


\section{Results}

Nineteen articles met our inclusion criteria ( $n=609$ participants). Individual study characteristics are shown in Table S1. Fifteen studies used dual energy x-ray absorptiometry (DEXA), whereas other studies used bioelectrical impedance [20], skinfolds [21], hydrostatic weighing [22], and air displacement plethysmography [23] to determine changes in body composition. Resistance training duration ranged from 7 to 52 weeks ( 2 to 3 times per week). Creatine supplementation protocols used both relative (to body mass) and absolute dosing strategies with and without a loading phase (e.g., 20 grams for five to seven days). Training volume increased with creatine supplementation compared to placebo in two studies [24,25], while several others reported no differences between groups $[22,23,26-30]$. In addition, dietary intake (energy intake or protein) did not differ between groups [21-24,26-38].

Mean changes and SD for mean changes for individual studies, and pooled effects and their $95 \%$ Cis are presented along with Forest plots in Figure $1 \mathrm{~A}-\mathrm{C}$. When pooling the data, body fat percentage (mean difference $=-0.55 \%(95 \% \mathrm{CI}=-1.08,-0.03) ; p=0.04)$ decreased to a greater extent after creatine supplementation compared to placebo. Absolute fat mass (mean difference $=-0.50 \mathrm{~kg}$ $(95 \% \mathrm{CI}=-1.15,0.15) ; p=0.13)$ and body mass (mean difference $=0.86 \mathrm{~kg}[95 \% \mathrm{CI}=-0.32,2.05]$; $p=0.15)$ were not statistically significant between conditions. To explore confounding factors, meta-analyses were re-analyzed with (1) male or female only studies, (2) DEXA only studies, or (3) removal of multi-ingredient supplement studies. Final meta-analyses remained unchanged. There was no evidence of publication bias from the funnel plots.

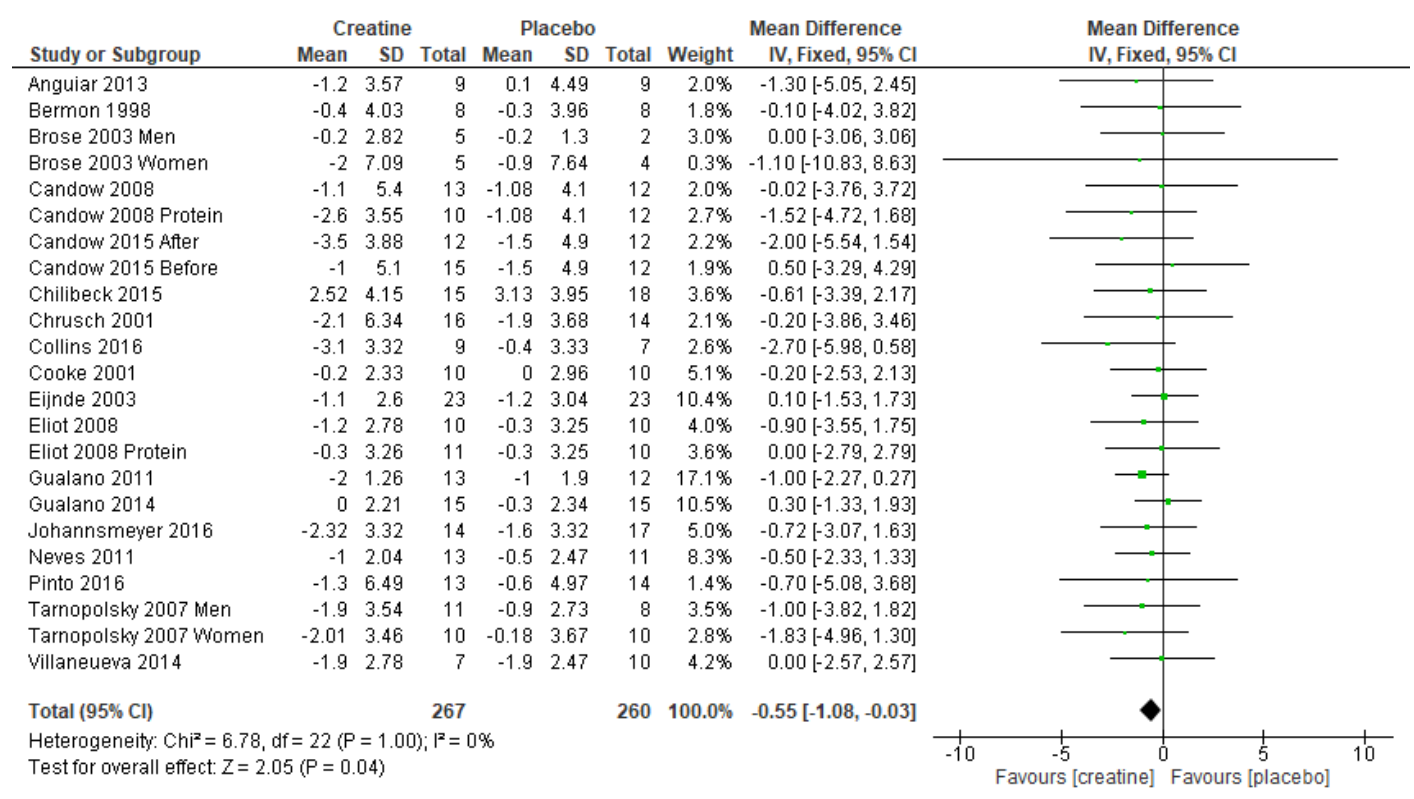

A

Figure 1. Cont. 


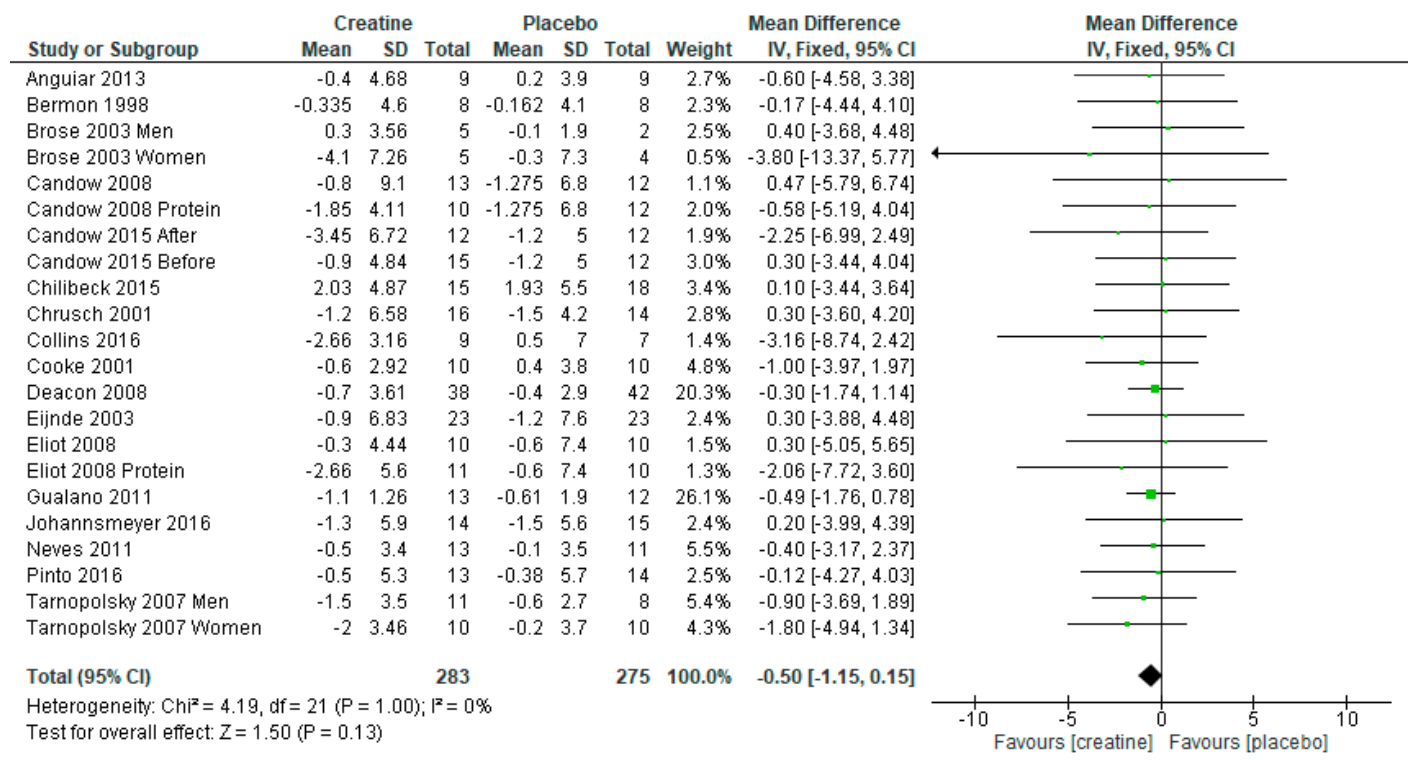

B

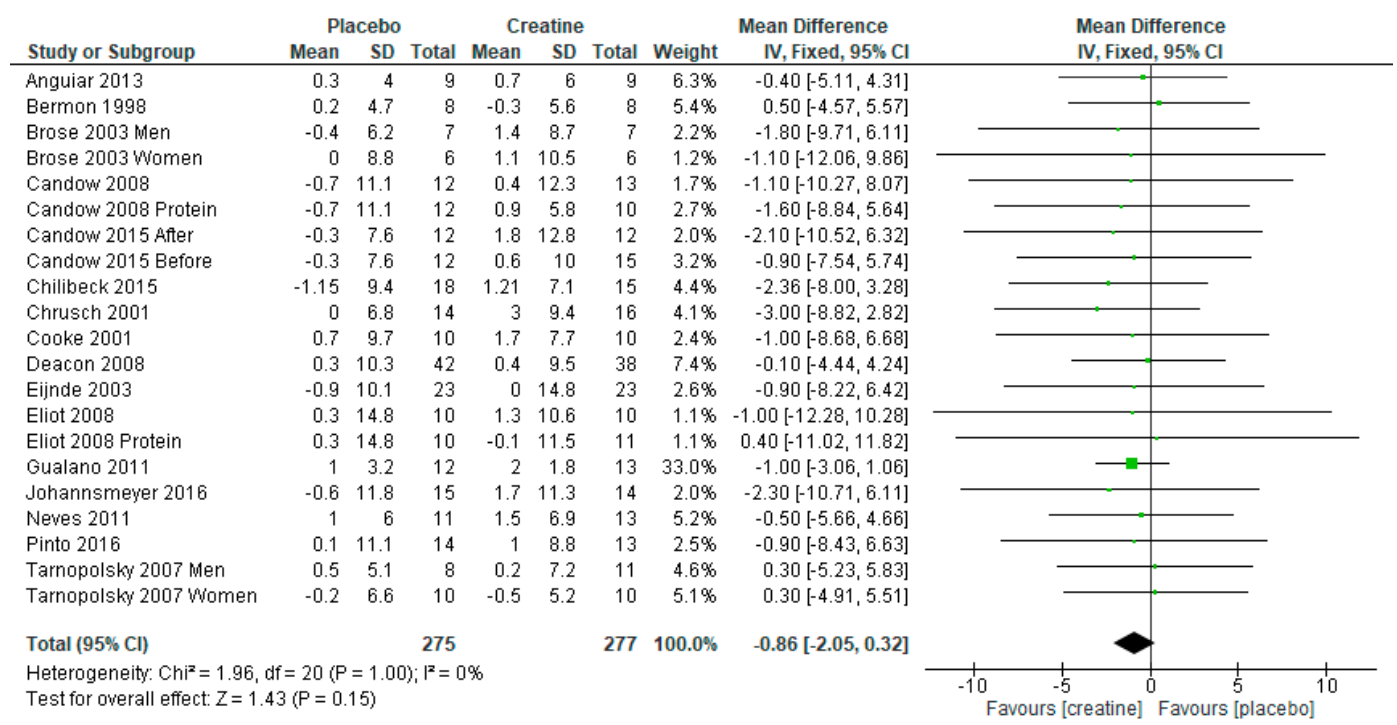

\section{C}

Figure 1. Forest plots for body fat percentage (\%) (A), absolute fat mass (kg) (B) and body mass $(\mathrm{kg})(\mathrm{C})$. Notes: Some studies presented data on men and women separately and on creatine and creatine + protein groups separately; therefore, these studies are entered twice in the meta-analysis for these separate subgroups. One study also presented data on participants who received creatine before versus after resistance training programs; therefore, these subgroups are entered separately in the meta-analysis.

\section{Discussion}

Results from this meta-analysis showed that adults $\geq 50$ years of age who supplemented with creatine during resistance training experienced a greater reduction in body fat percentage compared to placebo $(0.55 \%, p=0.04$; Figure $1 \mathrm{~A})$. Despite no statistical difference $(p=0.13)$, adults supplementing with creatine lost $\sim 0.5 \mathrm{~kg}$ more fat mass compared to those receiving placebo (Figure $1 \mathrm{~B}$ ). We propose that the decrease in body fat percentage and fat mass from creatine supplementation may be clinically relevant as the age-related accumulation in fat mass increases the risk for disease (i.e., cardiovascular, type II diabetes, obesity), morbidity and premature mortality [2]. 
Mechanistically, there is direct evidence that creatine influences certain aspects of adipocyte and fat tissue metabolism as well as triglyceride synthesis in multiple cell types. In an elegant study, Kazak et al. [18] crossed mice which harbored a floxed allele of the creatine transporter with transgenic Adipoq-cre mice. The offspring lacked the creatine transporter in fat tissue (i.e., AdCrTKO mice) which resulted in significantly lower creatine and phosphocreatine levels. Relative to control mice, AdCrTKO mice presented a reduction in whole-body energy expenditure, a decrease in oxidative metabolism in beige and brown adipose tissue, and an increase in feed efficiency and whole body adiposity. Furthermore, these authors obtained adipose tissue from human subjects and demonstrated that the mRNA expression of the creatine transporter was negatively associated with BMI. In interpreting these findings, the authors suggested that creatine stimulates mitochondrial ATP turnover in fat tissue which, in turn, increases the metabolic rate of subcutaneous and brown adipose tissue. Notably, similar research has shown that a decrease in the biosynthesis of creatine in the fat tissue of mice blunts whole-body energy expenditure and increases fat accumulation [17,19,39]. Lee et al. [40] also reported that creatine inhibited the formation of cytoplasmic triglycerides in multiple adipogenic cell culture models in a dose-dependent manner through the inhibition of PI3K-Akt-PPAR $\gamma$ signaling. Earnest et al. [41] determined that $5 \mathrm{~g} /$ day of creatine supplementation in hypercholesteremic participants significantly reduced plasma triglyceride levels by $\sim 20 \%$ after four to eight weeks of supplementation. While this effect was likely due to the inhibitory actions that creatine supplementation exerted on liver triglyceride synthesis, the collective evidence presented above suggests that the inhibitory effect that creatine has on triglyceride synthesis may also extend to adipose tissue. Results across in vitro and rodent studies indicate that creatine metabolism plays an important role in fat bioenergetics, and creatine supplementation positively influences energy expenditure. However, the effects of creatine supplementation on measures of lipolysis, energy expenditure and thermogenesis in aging adults remains to be determined.

Increased body mass (Figure 1C), combined with the decrease in fat mass and body fat percentage from creatine supplementation, may be indirectly related to and explained by greater muscle accretion from creatine supplementation and resistance training [12-14]. Greater lean tissue mass, which potentially increases resting metabolic rate and total daily energy expenditure (through increased participation in physical activities) [10,42] may possibly explain the decrease in fat mass and body fat percentage in aging adults supplementing with creatine. Furthermore, young males ( $21 \pm 3$ years of age) who supplemented with creatine ( $20 \mathrm{~g} /$ day for 5 days $+10 \mathrm{~g} /$ day for 23 days) during resistance training experienced a significant increase in lean tissue mass and resting metabolic rate/energy expenditure compared to resistance training and placebo [16].

\section{Conclusions}

In summary, this meta-analysis showed that creatine supplementation during resistance training has the potential to decrease body fat in adults $\geq 50$ years of age. Decreasing fat mass is important for reducing the risk of disease (cardiovascular, type II diabetes, obesity), morbidity and premature mortality. While the mechanisms explaining the potential decrease in fat mass remain to be determined in humans, preliminary rodent data suggests creatine influences fat bioenergetics, metabolism, and energy expenditure.

Supplementary Materials: The following are available online at http://www.mdpi.com/2411-5142/4/3/62/s1.

Author Contributions: Conceptualization, S.C.F., D.G.C., and J.R.K.; methodology, S.C.F, D.G.C., J.R.K.; formal analysis, S.C.F., D.G.C., J.R.K.; writing-original draft preparation, S.C.F., D.G.C., J.R.K., M.D.R., K.C.Y.; writing-review and editing, S.C.F., D.G.C., J.R.K., M.D.R., K.C.Y.

Funding: This research received no external funding.

Conflicts of Interest: The authors declare no conflicts of interest. 


\section{References}

1. Stenholm, S.; Vahtera, J.; Kawachi, I.; Pentti, J.; Halonen, J.I.; Westerlund, H.; Razak, F.; Subramanian, S.V.; Kivimaki, M. Patterns of weight gain in middle-aged and older US adults, 1992-2010. Epidemiology 2015, 26, 165-168. [CrossRef] [PubMed]

2. Wannamethee, S.G.; Atkins, J.L. Muscle loss and obesity: The health implications of sarcopenia and sarcopenic obesity. Proc. Nutr. Soc. 2015, 74, 405-412. [CrossRef] [PubMed]

3. Cruz-Jentoft, A.J.; Bahat, G.; Bauer, J.; Boirie, Y.; Bruyere, O.; Cederholm, T.; Cooper, C.; Landi, F.; Rolland, Y.; Sayer, A.A.; et al. Writing Group for the European Working Group on Sarcopenia in Older People 2 (EWGSOP2), and the Extended Group for EWGSOP2 Sarcopenia: Revised European consensus on definition and diagnosis. Age Ageing 2019, 48, 16-31. [CrossRef] [PubMed]

4. Elia, M.; Ritz, P.; Stubbs, R.J. Total energy expenditure in the elderly. Eur. J. Clin. Nutr. 2000, 54 (Suppl. 3), 92. [CrossRef]

5. Zamboni, M.; Mazzali, G.; Fantin, F.; Rossi, A.; Di Francesco, V. Sarcopenic obesity: A new category of obesity in the elderly. Nutr. Metab. Cardiovasc. Dis. 2008, 18, 388-395. [CrossRef] [PubMed]

6. Ogawa, S.; Yakabe, M.; Akishita, M. Age-related sarcopenia and its pathophysiological bases. Inflamm. Regen. 2016, 36, 5. [CrossRef] [PubMed]

7. Rizzoli, R.; Reginster, J.Y.; Arnal, J.F.; Bautmans, I.; Beaudart, C.; Bischoff-Ferrari, H.; Biver, E.; Boonen, S.; Brandi, M.L.; Chines, A.; et al. Quality of life in sarcopenia and frailty. Calcif. Tissue Int. 2013, 93, 101-120. [CrossRef] [PubMed]

8. Hart, P.D.; Buck, D.J. The effect of resistance training on health-related quality of life in older adults: Systematic review and meta-analysis. Health Promot. Perspect. 2019, 9, 1-12. [CrossRef] [PubMed]

9. Lopez, P.; Pinto, R.S.; Radaelli, R.; Rech, A.; Grazioli, R.; Izquierdo, M.; Cadore, E.L. Benefits of resistance training in physically frail elderly: A systematic review. Aging Clin. Exp. Res. 2018, 30, 889-899. [CrossRef]

10. Petridou, A.; Siopi, A.; Mougios, V. Exercise in the management of obesity. Metabolism 2019, 92, 163-169. [CrossRef]

11. Wyss, M.; Kaddurah-Daouk, R. Creatine and creatinine metabolism. Physiol. Rev. 2000, 80, 1107-1213. [CrossRef] [PubMed]

12. Candow, D.G.; Chilibeck, P.D.; Forbes, S.C. Creatine supplementation and aging musculoskeletal health. Endocrine 2014, 45, 354-361. [CrossRef] [PubMed]

13. Chilibeck, P.D.; Kaviani, M.; Candow, D.G.; Zello, G.A. Effect of creatine supplementation during resistance training on lean tissue mass and muscular strength in older adults: A meta-analysis. J. Sports Med. 2017, 8, 213-226. [CrossRef] [PubMed]

14. Devries, M.C.; Phillips, S.M. Creatine supplementation during resistance training in older adults-a meta-analysis. Med. Sci. Sports Exerc. 2014, 46, 1194-1203. [CrossRef] [PubMed]

15. Candow, D.G.; Forbes, S.C.; Chilibeck, P.D.; Cornish, S.M.; Antonio, J.; Kreider, R.B. Effectiveness of Creatine Supplementation on Aging Muscle and Bone: Focus on Falls Prevention and Inflammation. J. Clin. Med. 2019, 8. [CrossRef] [PubMed]

16. Arciero, P.J.; Hannibal, N.S.; Nindl, B.C.; Gentile, C.L.; Hamed, J.; Vukovich, M.D. Comparison of creatine ingestion and resistance training on energy expenditure and limb blood flow. Metabolism 2001, 50, 1429-1434. [CrossRef] [PubMed]

17. Kazak, L.; Chouchani, E.T.; Jedrychowski, M.P.; Erickson, B.K.; Shinoda, K.; Cohen, P.; Vetrivelan, R.; Lu, G.Z.; Laznik-Bogoslavski, D.; Hasenfuss, S.C.; et al. A creatine-driven substrate cycle enhances energy expenditure and thermogenesis in beige fat. Cell 2015, 163, 643-655. [CrossRef]

18. Kazak, L.; Rahbani, J.F.; Samborska, B.; Lu, G.Z.; Jedrychowski, M.P.; Lajoie, M.; Zhang, S.; Ramsay, L.C.; Dou, F.Y.; Tenen, D.; et al. Ablation of adipocyte creatine transport impairs thermogenesis and causes diet-induced obesity. Nat. Metab. 2019, 1, 360-370. [CrossRef]

19. Wakatsuki, T.; Hirata, F.; Ohno, H.; Yamamoto, M.; Sato, Y.; Ohira, Y. Thermogenic responses to high-energy phosphate contents and/or hindlimb suspension in rats. Jpn. J. Physiol. 1996, 46, 171-175. [CrossRef]

20. Deacon, S.J.; Vincent, E.E.; Greenhaff, P.L.; Fox, J.; Steiner, M.C.; Singh, S.J.; Morgan, M.D. Randomized controlled trial of dietary creatine as an adjunct therapy to physical training in chronic obstructive pulmonary disease. Am. J. Respir. Crit. Care Med. 2008, 178, 233-239. [CrossRef] 
21. Bermon, S.; Venembre, P.; Sachet, C.; Valour, S.; Dolisi, C. Effects of creatine monohydrate ingestion in sedentary and weight-trained older adults. Acta Physiol. Scand. 1998, 164, 147-155. [CrossRef] [PubMed]

22. Eijnde, B.O.; Van Leemputte, M.; Goris, M.; Labarque, V.; Taes, Y.; Verbessem, P.; Vanhees, L.; Ramaekers, M.; Vanden Eynde, B.; Van Schuylenbergh, R.; et al. Effects of creatine supplementation and exercise training on fitness in men 55-75 yr old. J. Appl. Physiol. (1985) 2003, 95, 818-828. [CrossRef] [PubMed]

23. Candow, D.G.; Little, J.P.; Chilibeck, P.D.; Abeysekara, S.; Zello, G.A.; Kazachkov, M.; Cornish, S.M.; Yu, P.H. Low-dose creatine combined with protein during resistance training in older men. Med. Sci. Sports Exerc. 2008, 40, 1645-1652. [CrossRef] [PubMed]

24. Aguiar, A.F.; Januario, R.S.; Junior, R.P.; Gerage, A.M.; Pina, F.L.; do Nascimento, M.A.; Padovani, C.R.; Cyrino, E.S. Long-term creatine supplementation improves muscular performance during resistance training in older women. Eur. J. Appl. Physiol. 2013, 113, 987-996. [CrossRef]

25. Chrusch, M.J.; Chilibeck, P.D.; Chad, K.E.; Davison, K.S.; Burke, D.G. Creatine supplementation combined with resistance training in older men. Med. Sci. Sports Exerc. 2001, 33, 2111-2117. [CrossRef] [PubMed]

26. Candow, D.G.; Vogt, E.; Johannsmeyer, S.; Forbes, S.C.; Farthing, J.P. Strategic creatine supplementation and resistance training in healthy older adults. Appl. Physiol. Nutr. Metab. 2015, 40, 689-694. [CrossRef] [PubMed]

27. Chilibeck, P.D.; Candow, D.G.; Landeryou, T.; Kaviani, M.; Paus-Jenssen, L. Effects of Creatine and Resistance Training on Bone Health in Postmenopausal Women. Med. Sci. Sports Exerc. 2015, 47, 1587-1595. [CrossRef]

28. Cooke, M.B.; Brabham, B.; Buford, T.W.; Shelmadine, B.D.; McPheeters, M.; Hudson, G.M.; Stathis, C.; Greenwood, M.; Kreider, R.; Willoughby, D.S. Creatine supplementation post-exercise does not enhance training-induced adaptations in middle to older aged males. Eur. J. Appl. Physiol. 2014, 114, 1321-1332. [CrossRef]

29. Gualano, B.; DE Salles Painneli, V.; Roschel, H.; Artioli, G.G.; Neves, M.; De Sa Pinto, A.L.; Da Silva, M.E.; Cunha, M.R.; Otaduy, M.C.; Leite Cda, C.; et al. Creatine in type 2 diabetes: A randomized, double-blind, placebo-controlled trial. Med. Sci. Sports Exerc. 2011, 43, 770-778. [CrossRef]

30. Johannsmeyer, S.; Candow, D.G.; Brahms, C.M.; Michel, D.; Zello, G.A. Effect of creatine supplementation and drop-set resistance training in untrained aging adults. Exp. Gerontol. 2016, 83, 112-119. [CrossRef]

31. Brose, A.; Parise, G.; Tarnopolsky, M.A. Creatine supplementation enhances isometric strength and body composition improvements following strength exercise training in older adults. J. Gerontol. A Biol. Sci. Med. Sci. 2003, 58, 11-19. [CrossRef]

32. Collins, J.; Longhurst, G.; Roschel, H.; Gualano, B. Resistance Training and Co-supplementation with Creatine and Protein in Older Subjects with Frailty. J. Frailty Aging 2016, 5, 126-134.

33. Eliot, K.A.; Knehans, A.W.; Bemben, D.A.; Witten, M.S.; Carter, J.; Bemben, M.G. The effects of creatine and whey protein supplementation on body composition in men aged 48 to 72 years during resistance training. J. Nutr. Health Aging 2008, 12, 208-212. [CrossRef]

34. Gualano, B.; Macedo, A.R.; Alves, C.R.; Roschel, H.; Benatti, F.B.; Takayama, L.; de Sa Pinto, A.L.; Lima, F.R.; Pereira, R.M. Creatine supplementation and resistance training in vulnerable older women: A randomized double-blind placebo-controlled clinical trial. Exp. Gerontol. 2014, 53, 7-15. [CrossRef]

35. Neves, M.; Gualano, B.; Roschel, H.; Fuller, R.; Benatti, F.B.; Pinto, A.L.; Lima, F.R.; Pereira, R.M.; Lancha, A.H.; Bonfa, E. Beneficial effect of creatine supplementation in knee osteoarthritis. Med. Sci. Sports Exerc. 2011, 43, 1538-1543. [CrossRef]

36. Pinto, C.L.; Botelho, P.B.; Carneiro, J.A.; Mota, J.F. Impact of creatine supplementation in combination with resistance training on lean mass in the elderly. J. Cachexia Sarcopenia Muscle 2016, 7, 413-421. [CrossRef]

37. Tarnopolsky, M.; Zimmer, A.; Paikin, J.; Safdar, A.; Aboud, A.; Pearce, E.; Roy, B.; Doherty, T. Creatine monohydrate and conjugated linoleic acid improve strength and body composition following resistance exercise in older adults. PLoS ONE 2007, 2, e991. [CrossRef]

38. Villanueva, M.G.; He, J.; Schroeder, E.T. Periodized resistance training with and without supplementation improve body composition and performance in older men. Eur. J. Appl. Physiol. 2014, 114, 891-905. [CrossRef]

39. Yamashita, H.; Ohira, Y.; Wakatsuki, T.; Yamamoto, M.; Kizaki, T.; Oh-ishi, S.; Ohno, H. Increased growth of brown adipose tissue but its reduced thermogenic activity in creatine-depleted rats fed beta-guanidinopropionic acid. Biochim. Biophys. Acta 1995, 1230, 69-73. [CrossRef] 
40. Lee, N.; Kim, I.; Park, S.; Han, D.; Ha, S.; Kwon, M.; Kim, J.; Byun, S.H.; Oh, W.; Jeon, H.B.; et al. Creatine inhibits adipogenesis by downregulating insulin-induced activation of the phosphatidylinositol 3-kinase signaling pathway. Stem Cells Dev. 2015, 24, 983-994. [CrossRef]

41. Earnest, C.P.; Almada, A.L.; Mitchell, T.L. High-performance capillary electrophoresis-pure creatine monohydrate reduces blood lipids in men and women. Clin. Sci. (Lond.) 1996, 91, 113-118. [CrossRef]

42. Bray, G.A.; Heisel, W.E.; Afshin, A.; Jensen, M.D.; Dietz, W.H.; Long, M.; Kushner, R.F.; Daniels, S.R.; Wadden, T.A.; Tsai, A.G.; et al. The Science of Obesity Management: An Endocrine Society Scientific Statement. Endocr. Rev. 2018, 39, 79-132. [CrossRef]

(C) 2019 by the authors. Licensee MDPI, Basel, Switzerland. This article is an open access article distributed under the terms and conditions of the Creative Commons Attribution (CC BY) license (http://creativecommons.org/licenses/by/4.0/). 